\title{
The effect of pattern of food supply on performance, compensatory growth and carcass composition of Beulah and Welsh Mountain lambs
}

\author{
G. R. Iason, A. R. Mantecont, J. A. Milne, D. A. Sim, A. D. M. Smith and I. R. White \\ Macaulay Land Use Research Institute, Craigiebuckler, Aberdeen AB9 2QS
}

\begin{abstract}
Seventy-eight Beulah (BH) and 78 Welsh Mountain (WM) wether lambs (mature live weights (MLW) 60 and $70 \mathrm{~kg}$ respectively), were used to investigate genotypic differences in performance and compensatory growth during the postweaning period. After an initial slaughter of 12 of each breed, a complete straw-based pelleted diet (122 g crude protein and 10.4 MJ metabolizable energy per $\mathrm{kg}$ dry matter (DM)) was offered ad libitum to a further 29 of each which were slaughtered at a range of live weights between proportionately 0.35 and $1.00 \mathrm{of} M L W$. As well as these groups undergoing normal growth (NG), the remaining lambs were given the same diet at a level sufficient to maintain constant live weight (LW) for 3 months. Eight of each breed were then slaughtered and the remaining 29 of each offered the diet ad libitum for a period of post-restricted growth (PRG); these 29 were also slaughtered between 0.35 and 1.00 of MLW. During the periods of ad libitum food supply, voluntary food intake was greater in BH than WM lambs (BH: 38.3, WM: $35.3 \mathrm{~g}$ DM per $\mathrm{kg} L W, P<0.01$ ) and during $P R G$ as compared with $N G$ although this result was due to a response only in WM lambs (NG - BH: 38.0, PRG-BH: 38.5, NG - WM: 33.3, PRG - WM: 37.2 g DM per kg LW, breed $\times$ pattern of food supply interaction, $\mathrm{P}<0.05$ ). Daily live-weight gain ( $L W G$ ) was greater during PRG than NG in both breeds (NG: 3.15, PRG: $4.80 \mathrm{~g} / \mathrm{kg} L W$ per day, P < 0.05). This effect was greatest in the first 8 weeks of growth but persisted into the period 16 weeks to maturity. WM lambs had overall slightly leaner carcasses and a lower proportion of protein in the fleece-free empty body than BH when compared at the same proportion of MLW; particularly during PRG. The protein in the carcass-weight gain (CWG) was greater in WM lambs during PRG than during NG (NG: 98, PRG: $123 \mathrm{~g} / \mathrm{kg}, \mathrm{P}<0.05)$, but did not differ significantly in BH (NG: 106, PRG: $118 \mathrm{~g} / \mathrm{kg}$ ). The proportion of fat in CWG was concomitantly smaller during PRG. There are thus breed differences in the performance and carcass composition of lambs during compensatory growth. Genotypes to be finished by continuous feeding or a regimen incorporating food restriction should be carefully chosen for date of finishing in relation to desired carcass composition.
\end{abstract}

Keywords: carcass composition, food supply, growth, lambs.

\section{Introduction}

Periodic restriction of food supply is an important natural component of animal production systems in seasonal environments. This natural restriction can be overcome with supplementary feeding or alternatively it can be incorporated as a normal part of the annual cycle of production. This is especially feasible when considering impairment of growth of young animals which can be made good by compensatory growth when adequate food supply is restored (O'Donovan, 1984). The experiment here was designed to examine the effect of food restriction

+ Present address: CSIC, Estacion Agricola Experimental, Apartado 788, 24080 Leon, Spain. and realimentation on performance, growth and carcass composition of Beulah and Welsh Mountain lambs, two breeds commonly produced on Welsh upland and hill farms.

Larger genotypes of sheep reach their mature live weight (MLW) at older ages than smaller genotypes (Taylor, 1980). This leads to differences in carcass composition when compared at the same live weight (LW) but most of these differences disappear when genotypes are compared at the same proportion of MLW (McClelland and Russel, 1972; McClelland, Bonaiti and Taylor, 1976; Butler-Hogg, 1984a). As well as being a function of stage of maturity, the chemical composition of the growth of the empty 
Table 1 Composition of diet

\begin{tabular}{lc}
\hline \hline Ingredients & $\mathrm{g} / \mathrm{kg}$ \\
\hline Barley straw (chopped) & 150 \\
Dried sugar beet pulp & 350 \\
Dried grass (milled) & 450 \\
Vitamin/mineral/molasses & 50 \\
Analysis & $10 \cdot 4$ \\
Estimated metabolizable energy (M)/kg DM) & 897 \\
Dry matter (g/kg) & 926 \\
Organic matter (g/kg DM) & 122 \\
Crude protein (g/kg DM) & 454 \\
Neutral-detergent fibre (g/kg DM) & \\
\hline
\end{tabular}

body and/or the carcass has been shown to differ between animals given food ad libitum following normal uninterrupted growth (normal growth; NG) and those on an ad libitum food supply following a period of intake restriction (post-restricted growth; PRG). Growth usually consists of more protein and less fat during PRG than during NG (Burton, Anderson and Reid, 1974; Butler-Hogg, 1984b; Hodge and Star, 1984) although other studies have shown that the fat content of the empty body may be greater at slaughter following realimentation to the same body weight as continuously fed controls (Meyer and Clawson, 1964; see also O'Donovan, 1984). The lack of agreement between studies may be due to differences in the precise treatments applied and/or the compensatory growth response may differ between breeds of sheep. This study aimed to compare two genotypes of lamb of contrasting MLW (Beulah (BH): $60 \mathrm{~kg}$; Welsh Mountain (WM): $50 \mathrm{~kg}$ ) given the same dietary restriction.

\section{Material and methods}

Animals

In August 1986, 78 Beulah and 78 Welsh mountain wether lambs were selected, each from a single flock in Dyfed, mid Wales. Both flocks lambed in April 1986 and after weaning in August, lambs were transported to Bush Estate, Midlothian, Scotland, where they were individually penned in indoor accommodation under natural lighting and temperature regimes. The mean initial live weights of the lambs were $21.7 \mathrm{~kg}$ for $\mathrm{BH}$ and $21.8 \mathrm{~kg}$ for WM.

\section{Experimental design}

For each of the two genotypes an initial group of 12 lambs was slaughtered in September (group I) and 29 others were offered the complete chopped-strawbased diet (Table 1) ad libitum. During this period of continuous ad libitum feeding and NG the 29 lambs of each breed were slaughtered at weights distributed evenly between proportionately 0.35 and 1.0 of MLW for that genotype. A further 37 of each breed were restricted to constant LW for 3 months after which time eight of each were slaughtered (group C). Restriction to constant LW was achieved by offering lambs $17.3 \mathrm{~g}$ dry matter (DM) per kg LW of the diet (Agricultural Research Council, 1980). The remaining 29 of each breed were realimented and received ad libitum feeding. These remaining lambs were slaughtered throughout the interval of 0.35 to 1.0 of MLW during this period of PRG. MLW was taken to be the breed average of $50 \mathrm{~kg}$ for WM (Meat and Livestock Commission, 1989) and was estimated at the outset of the experiment to be $60 \mathrm{~kg}$ for $\mathrm{BH}$ although no known published figure was available.

Table 2 Live-weight gains and food intakes of Beulah and Welsh Mountain lambs fed continuously ad libitum (NG) or during ad libitum feeding following restriction (PRG) in three periods during the time of growth

\begin{tabular}{|c|c|c|c|c|c|c|c|}
\hline \multirow[b]{3}{*}{ Dietary treatment } & \multicolumn{6}{|c|}{ Period } & \multirow[b]{3}{*}{ s.e.d. } \\
\hline & \multicolumn{2}{|c|}{0 to 8 weeks } & \multicolumn{2}{|c|}{9 to 16 weeks } & \multicolumn{2}{|c|}{16 weeks to maturity } & \\
\hline & NG & PRG & NG & PRG & NG & PRG & \\
\hline \multicolumn{8}{|l|}{ Beulah } \\
\hline Proportion of MLWt $(60 \mathrm{~kg})$ & 0.43 & 0.44 & 0.52 & 0.60 & 0.70 & 0.78 & - \\
\hline $\mathrm{LWG}(\mathrm{g} /$ day $)$ & $82 \cdot 4$ & $177 \cdot 5$ & $115 \cdot 4$ & $157 \cdot 0$ & $143 \cdot 1$ & 181.8 & $20 \cdot 28$ \\
\hline LWG (g/kg LW per day) & $3 \cdot 80$ & 6.77 & 3.69 & $4 \cdot 38$ & 3.00 & 3.89 & $0 \cdot 610$ \\
\hline Intake (g DM per day) & 962 & 1028 & 1174 & 1308 & 1316 & 1431 & $72 \cdot 8$ \\
\hline Intake (g DM per kg LW per day) & $39 \cdot 8$ & 39.8 & $38 \cdot 6$ & $37 \cdot 3$ & $28 \cdot 6$ & $31 \cdot 4$ & 2.05 \\
\hline \multicolumn{8}{|l|}{ Welsh Mountain } \\
\hline Proportion of MLWt $(50 \mathrm{~kg})$ & 0.47 & 0.53 & 0.59 & 0.72 & 0.84 & 0.94 & - \\
\hline LWG (g/day) & $48 \cdot 6$ & $144 \cdot 4$ & $113 \cdot 7$ & $178 \cdot 3$ & $106 \cdot 9$ & $157 \cdot 0$ & $18 \cdot 59$ \\
\hline LWG (g/kg LW per day) & 2.07 & $5 \cdot 43$ & $3 \cdot 87$ & 4.98 & $2 \cdot 48$ & $3 \cdot 33$ & $0 \cdot 60$ \\
\hline Intake (g DM per day) & 725 & 999 & 1027 & 1295 & 1180 & 1467 & $57 \cdot 8$ \\
\hline Intake (g DM per kg LW per day) & 31.5 & 37.5 & 34.9 & $36 \cdot 2$ & $27 \cdot 9$ & $31 \cdot 1$ & $1 \cdot 60$ \\
\hline
\end{tabular}

+ Proportion of mature live weight (MLW) was calculated at the chronological median of each period. 
Table 3 Probability values of main effects and interactions between factors from three-way analyses of variance, factorial design of the mass-specific live-weight gain (LWG) and food intake (see Table 2)

\begin{tabular}{lcc}
\hline \hline & $\begin{array}{c}\text { LWG } \\
\text { (g/kg LW } \\
\text { per day) }\end{array}$ & $\begin{array}{c}\text { Intake } \\
\text { (g DM per kg } \\
\text { LW per day) }\end{array}$ \\
\hline Breed (BH, WM) & $*$ & $* * *$ \\
Period (0 to 8, 9 to 16, 16+ weeks) & $* * *$ & $* * *$ \\
Pattern of food supply (NG, PRG) & $* * *$ & $* *$ \\
Breed $\times$ period & $* *$ & $*$ \\
Breed $\times$ pattern of food supply & $* * *$ & $*$ \\
$\begin{array}{l}\text { Period } \times \text { pattern of food supply } \\
\text { Breed } \times \text { period } \times \text { pattern } \\
\text { of food supply }\end{array}$ & \\
\hline \hline
\end{tabular}

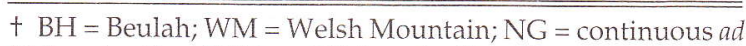
libitum feeding; PRG = ad libitum feeding after restriction .

In this experiment, five $\mathrm{BH}$ and four $\mathrm{WM}$ lambs fed ad libitum reached 'maturity' as defined by their mean LW remaining stable over a 4 -week period, and these means were $58 \mathrm{~kg}$ and $52 \mathrm{~kg}$ respectively.

\section{Measurements}

Following a 2-week period of adjustment to the diet, the amounts of food offered and refused and thus the voluntary food intake (VFI) by each lamb were recorded daily; LWs were recorded weekly. During periods of ad libitum feeding, food offered was adjusted to exceed intake by $100 \mathrm{~g} / \mathrm{kg}$. Lambs were shorn prior to slaughter. At slaughter the gastrointestinal tract was weighed full and empty. The pelt, feet, head and internal organs were weighed separately and combined with the empty gastrointestinal tract to form the non-carcass component. The complete carcass was weighed 'hot', chilled and split medially. One-half was retained and frozen at $-20^{\circ} \mathrm{C}$ for subsequent mincing. The minced carcass and non-carcass components were chemically analysed for fat, ash and water; protein was determined by difference.

\section{Results and discussion}

Intake, $L W G$ and food conversion ratio

As expected absolute VFI (g DM per day) was higher in the larger $\mathrm{BH}$ lambs but intake relative to $\mathrm{LW}$ was also greater in this breed (BH: 38.3 , WM: $35.3 \mathrm{~g}$ DM per $\mathrm{kg}$ per day). Although some studies have shown no significant increase in VFI on realimentation over and above those on continuous ad libitum feeding (e.g. Meyer and Clawson, 1964; Murray and

Table 4 (a) The proportion of carcass and fleece-free empty body (FFEB) in the live weight (LW) and the composition of (b) carcass and (c) FFEB of lambs in the initial slaughter group (I), the slaughter group following restriction $(C)$ and during growth periods on normal ad libitum-fed growth (NG) and post-restricted growth $(P R G)$, categorized into three stages of maturity

\begin{tabular}{|c|c|c|c|c|c|c|c|c|c|c|}
\hline & \multirow[b]{2}{*}{ Breedt } & \multirow[b]{2}{*}{ I } & \multirow[b]{2}{*}{ C } & \multicolumn{3}{|c|}{ NG } & \multicolumn{3}{|c|}{ PRG } & \multirow[b]{2}{*}{ s.e.d. } \\
\hline & & & & $0 \cdot 4-0 \cdot 6$ & $0 \cdot 6-0 \cdot 8$ & $0 \cdot 8-1 \cdot 0$ & $0 \cdot 4-0 \cdot 6$ & $0.6-0.8$ & $0 \cdot 8-1 \cdot 0$ & \\
\hline \multicolumn{11}{|c|}{$\begin{array}{l}\text { (a) Proportion of carcass and } \\
\text { FFEB in the LW }\end{array}$} \\
\hline \multirow[t]{2}{*}{ Carcass in LW } & $\mathrm{BH}$ & 0.504 & 0.445 & 0.482 & 0.489 & 0.531 & $0 \cdot 475$ & 0.504 & 0.504 & 0.0114 \\
\hline & WM & 0.518 & 0.448 & 0.474 & 0.487 & 0.485 & 0.444 & $0 \cdot 458$ & 0.464 & 0.0114 \\
\hline \multirow[t]{2}{*}{ FFEB in LW } & $\mathrm{BH}$ & 0.863 & 0.806 & 0.838 & 0.845 & 0.836 & 0.829 & 0.828 & 0.840 & 0.0120 \\
\hline & WM & $0 \cdot 874$ & 0.826 & 0.842 & 0.845 & $0 \cdot 845$ & 0.822 & $0 \cdot 813$ & 0.833 & 0.0199 \\
\hline \multicolumn{11}{|c|}{ (b) Composition of carcass } \\
\hline Water & WM & $\begin{array}{l}0.487 \\
0.464\end{array}$ & $\begin{array}{l}0.495 \\
0.488\end{array}$ & $\begin{array}{l}0.458 \\
0.452\end{array}$ & $\begin{array}{l}0.467 \\
0.420\end{array}$ & $\begin{array}{l}0.381 \\
0.401\end{array}$ & $\begin{array}{l}0.462 \\
0.481\end{array}$ & $\begin{array}{l}0.458 \\
0.433\end{array}$ & $\begin{array}{l}0.420 \\
0.464\end{array}$ & 0.0179 \\
\hline \multirow[t]{2}{*}{ Fat } & $\mathrm{BH}$ & 0.225 & 0.256 & 0.321 & 0.327 & 0.438 & 0.292 & $\begin{array}{l}0.433 \\
0.318\end{array}$ & $\begin{array}{l}0.464 \\
0.390\end{array}$ & $\begin{array}{l}0.0198 \\
0.0226\end{array}$ \\
\hline & WM & $0 \cdot 260$ & 0.250 & $0 \cdot 319$ & 0.379 & 0.403 & 0.265 & $0 \cdot 291$ & 0.358 & 0.0276 \\
\hline \multirow[t]{2}{*}{ Ash } & $\mathrm{BH}$ & 0.059 & 0.059 & 0.038 & 0.036 & 0.034 & 0.050 & 0.047 & 0.038 & 0.0047 \\
\hline & WM & 0.052 & 0.065 & 0.046 & 0.039 & $0 \cdot 041$ & 0.052 & 0.041 & 0.042 & 0.0045 \\
\hline \multirow[t]{2}{*}{ Protein } & $\mathrm{BH}$ & $0 \cdot 225$ & $0 \cdot 190$ & $0 \cdot 184$ & 0.170 & 0.147 & 0.196 & $0 \cdot 177$ & $0 \cdot 152$ & 0.0095 \\
\hline & \multicolumn{6}{|c|}{ (c) Composition of FFEB } & 0.202 & $0 \cdot 188$ & 0.168 & 0.0130 \\
\hline \multirow[t]{2}{*}{ Water } & $\mathrm{BH}$ & 0.547 & 0.536 & 0.510 & 0.499 & 0.422 & 0.510 & 0.508 & 0.460 & 0.0138 \\
\hline & WM & 0.516 & 0.536 & 0.508 & 0.474 & 0.445 & 0.525 & 0.523 & 0.477 & 0.0141 \\
\hline \multirow[t]{2}{*}{ Fat } & $\mathrm{BH}$ & 0.192 & 0.222 & 0.272 & 0.286 & 0.379 & 0.258 & 0.280 & 0.344 & 0.0197 \\
\hline & WM & 0.230 & 0.217 & 0.267 & 0.309 & 0.366 & 0.237 & 0.252 & 0.323 & 0.0199 \\
\hline \multirow[t]{2}{*}{ Ash } & $\mathrm{BH}$ & 0.049 & 0.049 & 0.039 & 0.034 & 0.032 & 0.044 & $0 \cdot 042$ & 0.037 & 0.0032 \\
\hline & WM & 0.043 & 0.052 & 0.039 & 0.034 & 0.035 & 0.044 & 0.037 & 0.034 & 0.0028 \\
\hline \multirow[t]{2}{*}{ Protein } & BH & $0 \cdot 212$ & 0.194 & $0 \cdot 180$ & $0 \cdot 182$ & 0.166 & $0 \cdot 188$ & 0.171 & 0.159 & 0.0096 \\
\hline & WM & 0.206 & 0.195 & 0.186 & $0 \cdot 183$ & 0.154 & 0.193 & 0.189 & 0.166 & 0.0091 \\
\hline
\end{tabular}

$\mathrm{BH}=$ Beulah; $\mathrm{WM}=$ Welsh Mountain. 
Slezacek, 1980), this study concords with others that have found that VFI during PRG is greater than that during NG (NG: 35.7 , PRG: $37.9 \mathrm{~g}$ DM per $\mathrm{kg}$ LW per day, $P<0.01$ ) (Allden, 1970; Graham and Searle, 1979). However, this overall greater VFI in PRG than NG groups is due solely to an effect within WM lambs (breed $X$ pattern of food supply interaction, $P<0.05$, Tables 2, 3)

Both absolute LWG and LWG relative to body weight were greater for $\mathrm{BH}$ than for WM lambs $(\mathrm{BH}$, 4.25: WM, $3.69 \mathrm{~g} / \mathrm{kg}$ LW per day, $P<0.05$ ) and overall LWG during PRG was greater than during NG (NG, 3.15; PRG, $4.80 \mathrm{~g} / \mathrm{kg} \mathrm{LW}$ per day, $P<0.001$ ), an effect present in both breeds (breed $X$ pattern of food supply interaction, $P>0.05$, Table 3 ). A short-term increase in VFI on realimentation is almost inevitable as animals are released from food restriction. This leads to immediate increases in LWG due to gutfill (Thornton, Hood, Jones and Re, 1979). Intake and LWG were hence calculated on a chronological basis in order to investigate the time course and persistence of any effects of PRG $v$. NG on these variables (Tables 2,3). In WM lambs, the LWG remained higher in the PRG group than the NG group into the period 9 to 16 weeks following return to ad libitum feeding. This elevation in LWG was not accompanied by a correspondingly elevated VFI by WM lambs in this same period. The elevation in LWG also resulted in the WM lambs reaching a greater proportion of their MLW (0.72) in this period, relative to all $\mathrm{BH}$ lambs and to $\mathrm{WM}$ lambs undergoing normal growth (Table 2). When analysed on a chronological basis (Table 2), the proportions of
MLW at slaughter are more divergent with increasing age during PRG than during NG.

Carcass and empty body weights and their composition In agreement with established allometric relationships (Thonney, Taylor, Murray and McClelland, 1987b), the BH lambs have a larger carcass relative to LW than the WM lambs, when compared at the same proportion of MLW (Table 4a). This breed difference is present within lambs on both NG and PRG, although the proportion of carcass in the LW is generally greater during normal growth as compared with compensatory growth. In contrast the fleece-free empty body weight (FFEBW) formed a relatively constant proportion of $\mathrm{LW}$, varying little either with dietary treatment or genotype (Table 4a). Thus compensatory growth, especially that occurring soon after realimentation was due mainly to an increase in non-carcass components; a similar result has been found in steers and sheep (Winter, Tulloh and Murray, 1976; Carstens, Johnson and Ellenberger, 1989). Clearly, since carcass components are a greater proportion of $\mathrm{LW}$ in $\mathrm{BH}$ than in WM lambs, then so the relative size of the non-carcass components are smaller in the $\mathrm{BH}$ breed. Whilst it may be hypothesized that variation in the proportions of non-carcass components are due to changes in the digestive tract (e.g. Carstens et al. 1989), there are no a priori grounds for expecting that either breed should have a relatively larger digestive tract. This body characteristic does not vary systematically with LW either between genotypes of sheep (Thonney et al., 1987b) or between species (Demment and Van Soest, 1985).

Table 5 Relationships between (a) carcass and fleece-free empty body components and live weight (LW) and (b) carcass components and Table 5 Relationships between (a) carcass and fleece-free empty body components and live weight (LW) and (b) carcass components and
carcass weight during normal continuous ad libitum-fed growth (NG) and ad libitum-fed growth post restriction (PRG) ( $\mathrm{S}_{a}$ and $\mathrm{S}_{b}$ are standard errors of estimated parameters)

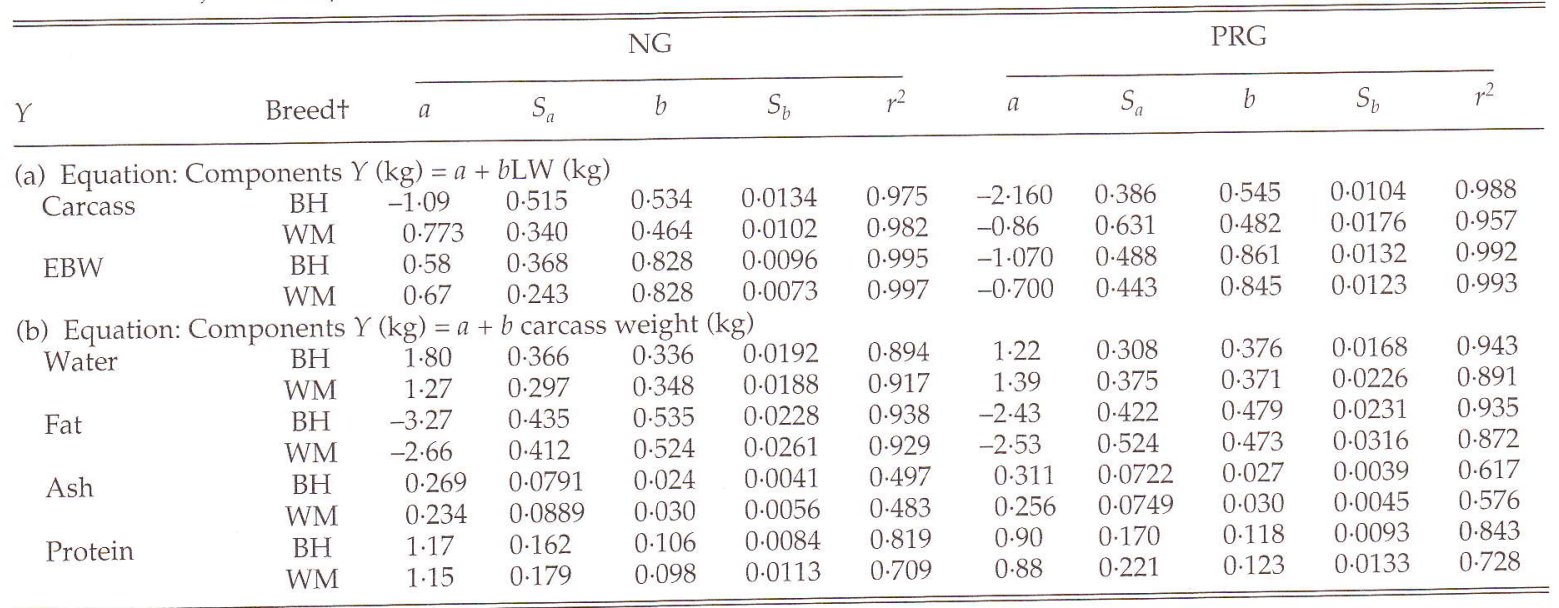

$+\mathrm{BH}=$ Beulah; $\mathrm{WM}=$ Welsh Mountain. 
The experiment confirms the general conclusions that the effect of food restriction and realimentation on carcass composition results in an overall lower proportion of fat in the carcass, a greater water content and a slightly greater proportion of protein (O'Donovan, 1984). This is especially true in WM lambs in which the proportion of carcass protein in the PRG group is greater than that in the NG group by $20 \mathrm{~g} / \mathrm{kg}$ in the early stages of growth, a difference which persisted until 0.8 to 1.0 of maturity (proportion of protein: PRG: $168 \mathrm{~g} / \mathrm{kg}$; NG: $149 \mathrm{~g} / \mathrm{kg}$ ). In $\mathrm{BH}$ lambs the proportion of protein was only $12 \mathrm{~g} / \mathrm{kg}$ greater in the PRG than the NG lambs at the early stages of growth, but this difference had largely disappeared by the time the lambs were at 0.8 to 1.0 of maturity (proportion of protein: PRG: $152 \mathrm{~g} / \mathrm{kg}$; NG: 147 g/kg; Table 4).

Composition of carcass gain

The relationship between weight of fat and empty body weight has been shown by some studies to be biphasic with an increase in rate of fattening above a transition point (Searle and Griffiths, 1976). It has been proposed that the transition point is at heavier body weights for animals of greater MLW (Black, 1983). Like many of the comparisons between breeds, this difference may also disappear if the transition points are considered to be a proportion of MLW (McClelland et al., 1976). In this experiment the gain in components of the carcass was found to be a linear function of carcass weight (Table 5) and there was no evidence of biphasic relationships or curvilinearity. There was no difference between breeds in the proportion of fat or protein in the carcass gain within the different patterns of food supply. There was significantly more protein and water and less fat in the carcass gain of both genotypes during PRG than during NG (Table 5). Several other studies have alse found a similar result, which is consistent with the hypothesis that compensatory growth is due to this change in chemical composition of the LWG (Black, 1983). The increase in carcass protein gain during PRG as compared with NG was greater in WM lambs (PRG: $125 \mathrm{~g} / \mathrm{kg}$; NG: $98 \mathrm{~g} / \mathrm{kg}, P<0.05$ ) than in BH lambs (PRG: $118 \mathrm{~g} / \mathrm{kg}$; NG: $106 \mathrm{~g} / \mathrm{kg}$, $P>0 \cdot 05)$.

Mechanisms of compensatory growth

The results have shown a greater compensatory growth response in WM than in BH lambs both in terms of LWG and protein composition of the carcass and EBW. It has been suggested that age and/or LW at the time of food restriction influence compensatory growth (see O'Donovan, 1984). When the experiment was begun, these lambs were of both similar age and LW, hence neither factor can explain the difference between these breeds. An alternative hypothesis is that the potential for compensatory growth depends on the body composition at the time of restriction. Wright, Russel and Hunter (1987) proposed that cattle may exhibit compensatory growth if restriction is applied at a stage when nutrition can influence the quantity of fat deposited. The fat composition of both the carcass and the FFEBW of the WM lambs was slightly but not significantly greater than that of the $\mathrm{BH}$ lambs at the start of the experiment (Table 4). In this regard the results here would tend to support the hypothesis of Wright et al. (1987) in that food restriction had a greater effect on fatness of WM lambs which subsequently showed greater compensatory growth; this may have been a consequence of the WM lambs being at a greater proportion of their MLW than the $\mathrm{BH}$ lambs at the onset of the experiment. Surprisingly, the WM lambs actually decreased in proportion of fat in both the carcass and the FFEBW during restriction as compared with the $\mathrm{BH}$, which increased their proportion of fat (Table 4), although the changes were small. Changes in fatness during restriction and utilization of fat after restriction may both be a result of a generally greater propensity of some genotypes to reallocate body reserves.

We cannot at this stage discern whether the difference in compensatory growth between the breeds is a consequence of fat dynamics, stage at which restriction is imposed relative to maturity or an inherently faster maximum growth rate in the WM breed. The results for both breeds however do support the general principle that compensatory growth is due primarily to protein gain early in the period of realimentation (Black, 1983). A comparative study of lambs has shown that genotypes of small mature LW reach maturity at younger ages (Thonney, Taylor and McClelland, 1987a). It was also shown that WM lambs mature more rapidly than predicted on the basis of their small mature size (Thonney et al., 1987a). This rapid growth characteristic seems to be exaggerated further when considering compensatory growth. This may be a genotypic characteristic which is related to differences in metabolic rate (Derting, 1989).

Compensatory growth: the trade-off between food inputs, carcass composition and finishing date

The overall results of this experiment are summarized in Table 6. When reared on an ad libitum feeding regimen, at the same proportion of mature LW, the BH lambs provide larger carcasses with a slightly greater proportion of fat, but they take a longer time and hence more food to reach this stage than WM lambs (Table 6a). When lambs are reared to the same carcass weight of $16 \mathrm{~kg}, \mathrm{BH}$ lambs are at a correspondingly earlier stage of maturity, but reach the target carcass weight sooner and consume 
Table 6 Parameters relevant to animal production of Beulah (BH) and Welsh Mountain (WM) lambs when reared to slaughter at (a) 0.7 of mature live weight (MLW), (b) a carcass weight of $16 \mathrm{~kg}$, (c) slaughter at 200 days from weaning and (d) to a carcass containing $3.50 \mathrm{~kg}$ fat

\begin{tabular}{|c|c|c|c|c|c|c|c|c|c|c|c|c|c|c|c|c|c|c|c|}
\hline \multirow{3}{*}{$\begin{array}{l}\text { Genotype } \\
\text { Pattern of } \\
\text { food supply }\end{array}$} & \multicolumn{4}{|c|}{ LM/MLW } & \multicolumn{4}{|c|}{ Carcass weight (kg) } & \multicolumn{4}{|c|}{ Total intake (kg) } & \multicolumn{4}{|c|}{$\begin{array}{l}\text { Time weaning to } \\
\text { slaughter (days) }\end{array}$} & \multicolumn{3}{|c|}{ Carcass fat (kg) } \\
\hline & \multicolumn{2}{|c|}{$\mathrm{BH}$} & \multicolumn{2}{|c|}{ WM } & \multicolumn{2}{|c|}{$\mathrm{BH}$} & \multicolumn{2}{|c|}{ WM } & \multicolumn{2}{|c|}{$\mathrm{BH}$} & \multicolumn{2}{|c|}{ WM } & \multicolumn{2}{|c|}{$\mathrm{BH}$} & \multicolumn{2}{|c|}{ WM } & \multicolumn{2}{|c|}{$\mathrm{BH}$} & \multirow{2}{*}{$\frac{\text { WM }}{\text { NG PRC }}$} \\
\hline & $N G$ & PRG & NG & PRG & NG & PRG & NG & PRG & NG & PRG & NG & PRG & NG & PRG & NG & PRG & NG & PRG & \\
\hline (a) & 0.70 & $0 \cdot 70$ & $0 \cdot 70$ & $0 \cdot 70$ & 21 & 20 & 17 & 16 & 230 & 196 & 142 & 131 & 173 & 204 & 128 & 161 & $7 \cdot 96$ & $7 \cdot 63$ & $6.25 \quad 5.04$ \\
\hline (b) & 0.53 & 0.55 & 0.66 & $0 \cdot 70$ & 16 & 16 & 16 & 16 & 116 & 126 & 121 & 132 & 87 & 152 & 109 & 162 & $5 \cdot 29$ & $5 \cdot 23$ & 5.725 .04 \\
\hline (c) & 0.75 & 0.68 & $0 \cdot 84$ & 0.82 & 23 & 20 & 20 & 19 & 266 & 191 & 222 & 181 & 200 & 200 & 200 & 200 & 9.03 & $7 \cdot 15$ & $7.82 \quad 6.46$ \\
\hline (d) & 0.43 & 0.43 & $0 \cdot 48$ & 0.58 & 13 & 12 & 12 & 13 & 46 & 67 & 22 & 87 & 35 & 109 & 20 & 126 & $3 \cdot 50$ & 3.50 & $3.50 \quad 3.50$ \\
\hline
\end{tabular}

slightly less food in doing so (Table 6b). When given food ad libitum to this carcass weight, because they are at an earlier stage of growth relative to maturity, the $\mathrm{BH}$ lambs have slightly less fat in the carcass than do the WM lambs. These relative merits of the $\mathrm{BH}$ and the WM genotypes of lamb may also pertain to other genotypic comparisons of large $v$. small mature weight.

When a period of food restriction to maintain body weight was incorporated into the feeding regime, the total time taken to reach a target stage of maturity or carcass weight was inevitably increased. When reared to slaughter at lighter carcass weights or lower proportions of maturity within both $\mathrm{BH}$ and WM genotypes, the total food intake was higher in the restricted and realimented groups than in the continuously fed lambs (Tables $6 \mathrm{~b}, \mathrm{~d}$ ). When growth following restriction was continued to heavier carcass weights or larger proportions of maturity, then the total food supplied to achieve the equivalent carcass production was lower for the restricted and realimented lambs than for the continuously fed lambs (Tables 6a, c). Thus, it is possible to derive a net benefit in terms of reduced food input by food restriction and subsequently re-feeding ad libitum, but this can be achieved only if the lambs are grown to a later stage of maturity and/or heavier weight. Since one of the chief goals of a period of food restriction of lambs may well be to produce later finished carcasses, the requirement for a longer growth period is probably no disadvantage. There was a clear difference between the breeds in terms of the effect of restriction and realimentation on carcass composition. Although carcass and empty body compositions of the two breeds were very similar during NG, under conditions of PRG the WM lambs became relatively leaner and less fat than the $\mathrm{BH}$ lambs.

Many hill farms produce lambs on rough grazings and sell them to lower-lying farms after weaning where they may be finished before slaughter. In regions where this stratified system does not operate, as in Wales, and lambs are retained on their natal farm until slaughter, the merits of compensatory growth would be more important to the producer. On such hill farms, the strong seasonality of the environment means that low availability of overwinter grazing is a prominent characteristic providing natural circumstances of food restriction. The results here demonstrate the need to make careful choices of genotype suitable for using compensatory growth to maximum effect. The specific aims of the production system, but notably the desired timing of finishing and the carcass quality, should be considered.

\section{Acknowledgements}

We thank Drs A. J. F. Russel and I. A. Wright for helpful comments and discussion.

\section{References}

Agricultural Research Council. 1980. The nutrient requirements of ruminant livestock. Commonwealth Agricultural Bureaux, Slough.

Allden, W. G. 1970. The effects of nutritional deprivation on the subsequent productivity of sheep and cattle. Nutritional Abstracts and Reviews 40: 1167-1184.

Black, J. L. 1983. Growth and development of lambs. In Sheep production (ed. W. Haresign), pp. 21-58. Butterworths, London.

Burton, J. H., Anderson, M. and Reid, J. T. 1974. Some biological aspects of partial starvation. The effect of weight loss and regrowth on body composition in sheep. British Journal of Nutrition 32: 515-527.

Butler-Hogg, B. W. 1984a. The growth of Clun and Southdown sheep: body composition and the partitioning of total body fat. Animal Production 39: 405-411.

Butler-Hogg, B. W. 1984b. Growth patterns in sheep changes in the chemical composition of the empty body and its constituent parts during weight loss and compensatory growth. Joumal of Agricultural Science, Cambridge 103: 17-24. 
Carstens, G. E., Johnson, D. E. and Ellenberger, M. A. 1989. Energy metabolism and composition of gain in beef steers exhibiting normal and compensatory growth. In Energy metabolism of farm animals (ed. Y. van der Honing and W. H. Close), proceedings of the 11th symposium, Netherlands, 1983, pp. 131-134.

Demment, M. W. and Van Soest, P. J. 1985. A nutritional explanation for body-size patterns of ruminant and nonruminant herbivores. American Naturalist 125: 641-672.

Derting, T. L. 1989. Metabolism and food availability as regulators of production in juvenile cotton rats. Ecology 70 : 587-595.

Graham, N. McC. and Searle, T. W. 1979. Studies of weaned lambs before, during and after a period of weight loss. I. Energy and nitrogen utilization. Australian Journal of Agricultural Research 30: 513-523.

Hodge, R. W. and Star, M. 1984. Comparison of the fat status of lambs during continuous growth and following nutritional restriction and subsequent re-alimentation. Australian Journal Experimental Agriculture and Animal Husbandry 24: 150-155.

McClelland, T. H. and Russel, A. J. F. 1972. The distribution of body fat in Scottish Blackface and Finnish Landrace lambs. Animal Production 15: 301-306.

McClelland, T. H., Bonaiti, B. and Taylor, St C. S. 1976. Breed differences in body composition of equally mature sheep. Animal Production 23: 281-293.

Meat and Livestock Commission. 1989. Lamb carcase production. 2nd ed. Meat and Livestock Commission, Bletchley.

Meyer, J. H. and Clawson, W. J. 1964. Undernutrition and subsequent realimentation in rats and sheep. Journal of Animal Science 23: 214-224.
Murray, D. M. and Slezacek, O. 1980. Growth pattern and its effect on feed utilization of sheep. Journal of Agricultural Science, Cambridge 95: 349-355.

O'Donovan, P. B. 1984. Compensatory gain in cattle and sheep. Nutrition Abstracts and Reviews, Series B 54:389-410.

Searle, T. W. and Griffiths, D. A. 1976. The body composition of growing sheep during milk feeding, and the effect on composition of weaning at various body weights. Journal of Agricultural Science, Cambridge 86: 483-493.

Taylor, St C. S. 1980. Live-weight growth from embryo to adult in domesticated mammals. Animal Production 31 223-235

Thonney, M. L., Taylor, St C. S. and McClelland, T. H. 1987a. Breed and sex differences in equally mature sheep and goats. 1. Growth and food intake. Animal Production 45: $239-260$

Thonney, M. L., Taylor, St C. S., Murray, J. I. and McClelland, T. H. 1987b. Breed and sex differences in equally mature sheep and goats. 2. Body components at slaughter. Animal Production 45: 261-276.

Thornton, R. F., Hood, R. L., Jones, P. N. and Re, V. M 1979. Compensatory growth in sheep. Australian Journal of Agricultural Research 30: 135-151.

Winter, W. H., Tulloh, N. M. and Murray, D. M. 1976. The effect of compensatory growth in sheep on empty body weight, carcass weight and the weights of some offals. Journal of Agricultural Science, Cambridge 87: 433-441.

Wright, I. A., Russel, A. J. F. and Hunter, E. A. 1987. The effects of genotype and post-weaning nutrition on compensatory growth in cattle reared as singles or twins. Animal Production 45: 423-432.

(Received 19 February 1991-Accepted 20 September 1991) 